\title{
Mercerization effect on the properties of LDPE/PHB composites reinforced with castor cake
}

\author{
Marisa Cristina Guimarães Rocha'* (D), Nancy Isabel Alvarez de Acevedo', \\ Carlos Ivan Ribeiro de Oliveira ${ }^{1}$, Maira Cunha Sanches ${ }^{1}$ and Natália Nogueira Coelho ${ }^{1}$ \\ ${ }^{1}$ Universidade do Estado do Rio de Janeiro - UERJ, Rio de Janeiro, RJ, Brasil \\ *mrocha@iprj.uerj.br
}

\begin{abstract}
The aim of this work was to investigate the effects of mercerization on the structure of castor oil cake (CC) and on the tensile properties of LDPE/PHB/CC composites. To achieve this goal, the fibers were treated with $\mathrm{NaOH}$ solutions ( 5 and $10 \mathrm{wt} \%$ ). Characterization techniques such as: scanning electron microscopy (SEM), X-ray diffraction (XRD) and Fourier transform infrared spectroscopy (FTIR) were used to investigate the structure of modified fibers. The composites were processed in a Haake mixer. Tensile tests of the composites were performed according to ASTM D638 standard. The analyzes revealed that mercerization promoted a partial conversion of cellulose I into cellulose II. Mercerization performed with $5 \% \mathrm{NaOH}$ solution improved the tensile properties of the LDPE/PHB/CC composites, which were superior to those obtained with the $10 \% \mathrm{NaOH}$ solution. This result suggests that the higher concentration of $\mathrm{NaOH}$ compromises the integrity of the fibers, deteriorating the mechanical properties.
\end{abstract}

Keywords: mercerization, castor oil cake, composites, fiber characterization, mechanical properties.

How to cite: Rocha, M. C. G., Acevedo, N. I. A., Oliveira, C. I. R., Sanches, M. C., \& Coelho, N. N. (2020). Mercerization effect on the properties of LDPE/PHB composites reinforced with castor cake. Polimeros: Ciência e Tecnologia, 30(4), e2020037. https://doi.org/10.1590/0104-1428.07720.

\section{Introduction}

Nowadays, the scientific community has boosted intense research and development efforts in order to exploit the potential of agricultural wastes and lignocellulosic materials as an alternative source of fibers in the polymer industry ${ }^{[1-3]}$. The reasons for this include growing interest in reducing the environment impact associated with discard of polymer-based materials; depletion of fossil fuel nonrenewable resources and better understanding of correlation between the structure and properties of natural materials ${ }^{[1-6]}$.

Natural fibers are very attractive for composites due to their low-cost, biodegradable nature, low density, desirable fiber aspect ratio, minimum health hazards and excellent mechanical properties ${ }^{[2,3,5,7]}$. Besides, the agricultural wastes are renewable sources of natural fibers ${ }^{[1-3]}$. However, the use of lignocellulosic fibers as reinforcing agent for the hydrophobic matrices presents some drawbacks due to the low interfacial adhesion properties between fiber and matrix ${ }^{[7,8]}$. The obtained composite exhibits poor properties such as high uptake of moisture that leads to obtaining poor mechanical properties and low dimensional stability. Chemical treatments on natural fiber are one of the alternative solutions to circumvent these problems ${ }^{[3,7]}$.

Mercerization is a process of subjecting a vegetable fiber to an interaction with a concentrated aqueous solution of strong base, to produce great swelling, with resulting changes in the fine structure, dimension, morphology and mechanical properties ${ }^{[7]}$. The type of alkali and its

concentration have influence on the degree of swelling, and therefore, on the degree of lattice transformation from the monoclinic crystalline lattice of cellulose I, presented by native cellulose, to-cellulose II, which is an allomorph polymorph of cellulose. There is some indication that sodium hydroxide $(\mathrm{NaOH})$ treatment results in a higher degree of swelling and leads to obtain the thermodynamically stable crystalline structure, cellulose $\mathrm{II}^{[7,8]}$.

Besides cellulose, natural fibers consist of others constituents like hemicelluloses, lignin, pectin and impurities such as wax, ash and natural oil ${ }^{[7]}$. The removal of these substances promotes changes in the topography of the fiber surface, increased roughness and the ratio between the length and diameter of the fiber in addition to a better dispersion of the filler particles in the polymer matrix resulting in superior mechanical properties ${ }^{[3,8-12]}$.

The degrees of phase conversion of cellulose depend on the concentration of sodium hydroxide, time and temperature of process ${ }^{[8,13]}$. According to some published studies, the conversion from cellulose I to II happens in $\mathrm{NaOH}$ solutions of concentration higher than $10 \%{ }^{[8]}$. However, there are some studies showing better mechanical behavior of composites in concentrations lower than $10 \%{ }^{[9]}$.

The chemical composition of similar types of natural fibers, as well as of different types of natural fibers will vary for each fiber. Therefore, the optimal conditions of 
mercerization will be dependent on the type of lignocellulosic material ${ }^{[8]}$.

In general, there is a positive effect of mercerization of natural fibers on the mechanical properties of the composites $^{[7,10,14-17]}$. However, some authors reported better mechanical properties for systems containing cellulose ${ }^{[8]}$.

Castor bean (Ricinuscommunis $L$ ) is of great economic importance due to the oil extracted from its seeds ${ }^{[18-21]}$. Castor oil is a valuable raw material for biodiesel production. Therefore, the valorization of the castor oil cake, co-product of biodiesel process production, contributes to improve the productive chain of biodiesel. Some few papers report the use of castor cake as filler for composites ${ }^{[22-28]}$. The addition of this filler seems to improve the mechanical behavior of the composites. There is also a patent claim for obtaining composite materials with enhanced biodegradability using castor oil cake as filler requested by a Brazilian Oil Industry ${ }^{[2]}$.

In a previous work, blends of low-density polyethylene (LDPE) and poly(3-hydroxybutyrate) (PHB) filled with castor oil pressed cake (CC) were developed. The results showed that the addition of a certain amount of PHB or CC to LDPE makes possible obtaining LDPE based materials with increased susceptibility to biodegradation. However, the poor interfacial adhesion became visible in all samples ${ }^{[28]}$.

This study aims to evaluate the effect of mercerization on the structure of castor oil cake. This investigation also seeks to assess the influence of this chemical treatment on the mechanical properties of LDPE/PHB blends filled with castor cake.

\section{Materials and Methods}

\subsection{Materials}

Low density polyethylene (LDPE, TS O728), $\mathrm{MFI}=2.20 \mathrm{~g} / 10 \mathrm{~min}-\mathrm{ASTM} \mathrm{D} 1238$, at $190{ }^{\circ} \mathrm{C}$, was donated by Petroquímica Triunfo S.A./BRASKEM (Brazil) and used as received. Poly(3-hydroxybutyrate) (PHB), MFI $=16 \mathrm{~g} / 10 \mathrm{~min}-\mathrm{ASTM} \mathrm{D} 1238$, at $190{ }^{\circ} \mathrm{C}$ was obtained from PHB Industrial S.A. (Brazil) and used as received. Bom-Brasil Óleo de Mamona Ltda. (Brazil) provided the castor oil pressed cake (CC). This material was detoxified by autoclaving at $120{ }^{\circ} \mathrm{C}$ for 30 minutes. After a drying process, the filler was ground in a ball mill and passed through a set of sieves with a decreasing mesh size. Only the powdered material with a size less or equal to $0.25 \mathrm{~mm}$ was used in this work. Sodium hydroxide $(\mathrm{NaOH})$ used for alkali treatment of castor oil cake was furnished by Vetec Química Fina Ltda (Brazil).

\subsection{Methods}

The methods used in this work are described below

\subsubsection{Alkali treatment of castor oil cakes}

The alkali treatment of castor oil cake was carried out by immersing the fibers in $5 \%$ and $10 \% \mathrm{NaOH}$ solution respectively, for 1 hour. Subsequently, the fibers were thoroughly washed with water to remove the $\mathrm{NaOH}$ in excess, and kept in distilled water for 24 hours. After this time, the fibers were washed with water again to remove the residual $\mathrm{NaOH}$, and kept in distilled water for another 24 hours. This procedure was repeated until $\mathrm{pH}$ values of the solution equal to 7 were obtained. The fibers were then oven dried at $80^{\circ} \mathrm{C}$ for 24 hours to remove the water in excess.

\subsubsection{Castor oil cake characterization}

Fourier transform spectroscopy (FTIR), X-ray diffraction (XRD) and Scanning electron microscopy (SEM) techniques were used to investigate the structure and morphology of the alkali treated castor oil cake.

Fourier Transform Spectroscopy (FTIR): FTIR spectra for $\mathrm{KBr}$ pellets containing untreated castor oil cake and alkali treated samples were recorded in the region of $600-4000 \mathrm{~cm}^{-1}$ with 120 scans and a $4 \mathrm{~cm}^{-1}$ resolution, using the Varian infrared spectrometer, Excalibur Series 3100 , equipped with a diamond crystal attenuated total reflectance (ATR) accessory.

X-Ray Diffraction (XRD): X-Ray diffraction data of untreated castor oil cake and $\mathrm{NaOH}$ treated samples, in powder form, were obtained using a Rigaku, Miniflex instrument. Ni-filtered $\mathrm{CuK} \alpha$ radiation $(\lambda=1.542 \AA)$ generated at a voltage of $30 \mathrm{kV}$ and current of $15 \mathrm{~mA}$, and a scan rate of $1 \%$ min in the $2 \theta$ range from $2^{\circ}$ to $40^{\circ}$ was used.

Scanning Electron Microscopy (SEM): The morphology of treated and untreated samples of castor oil cake was examined by using a scanning electron microscope, Hitachi Benchtop model TM 3000

\subsubsection{Mixtures Processing}

LDPE/PHB/CC, LDPE/PHB/CCM5 and LDPE/PHB/ CCM10 mixtures at $80 / 10 / 10 \mathrm{wt} \%$ were melt processed during 10 minutes in a Haake Rheomix OS, equipped with roller blades, at $150{ }^{\circ} \mathrm{C}$ and $50 \mathrm{rpm}$. CCM5 means castor cake treated with $5 \%$ of $\mathrm{NaOH}$ and CCM10 means castor cake treated with $10 \%$ of $\mathrm{NaOH}$.

\subsubsection{Determination of the Composites Tensile Properties}

Tensile properties were measured using an EMIC Universal Test Machine, Model DL 300 with a $10 \mathrm{kN}$ load cell. Tests were conducted in accordance with ASTM D 638 $8^{[30]}$. Type V test specimens were prepared using a Carver press at $69 \times 10 \mathrm{~N} / \mathrm{m}^{2}$ and $190^{\circ} \mathrm{C}$ for 15 minutes. A crosshead speed of $1 \mathrm{~mm} / \mathrm{min}$ was employed. Seven (7) specimens were used to analyze each sample.

\section{Results and Discussions}

\subsection{Characterization of the Fibers}

The effects of the alkali treatments on the surface of the castor oil cake were investigated by SEM (Figure 1).

All micrographs show the fibrous nature of castor oil cake. However, the removal of hemicelluloses, lignin and wax by the alkali treatment gave rise to thinner cellulose fibers and increased roughness (Figure 1d), which may promote greater contact area between these fibers with polymer matrices. The micropores were also more visible in the samples submitted to mercerization procedure. These results are in agreement with those obtained by others researchers ${ }^{[2,3,8,9,11,16,17]}$, which noted that the processes of mercerization determine the 
character of the filler fibrillation, promoting better adhesion between fibers and polymer matrix.

Figure 2 presents the FTIR characteristic features of untreated castor oil cake (CC) and alkali treated castor cake samples: MCC $5-5 \% \mathrm{NaOH}$ solution; $\mathrm{MCC} 10-10 \%$ $\mathrm{NaOH}$ solution.

The infrared indices (IR indices), (ratio of IR absorption band intensity at a given wavenumber to that at the reference wavenumber $)^{[31]}$, used in this work were based on the absorbance peaks at $1059 \mathrm{~cm}^{-1}(>\mathrm{CO} / \mathrm{C}-\mathrm{C} / \mathrm{COH}$ stretching vibration). These IR indices were chosen to analyse the possible changes of cellulose conformation, as well as the intensity changes of $\mathrm{OH}$ streching vibration and hydrogenbonds due to the alkali treatment of the castor cake. However, curve-fitting deconvolution methods must be used in order to avoiding erroneous results ${ }^{[32]}$.
It is well known that absorbance and/or wavenumber of most of the FTIR characteristic bands of cellulose changes with the alkali treatment ${ }^{[33]}$. The FTIR spectra of the samples under study provide some evidence that the fibers mercerization process has promoted the removal of lignin and hemicellulose.

A band at $2858 \mathrm{~cm}^{-1}$ observed in the spectrum of raw castor cake and in the spectrum of the castor oil cake treated with $5 \%$ of $\mathrm{NaOH}$ is attributed to the $-\mathrm{OH}$ stretching vibration of inter and intramolecular $\mathrm{H}$-bonding present in the cellulose, hemicellulose and lignin molecules of castor oil cake making the resulting structure as a network. This strucure was gradually destroyed and disappered, when a $10 \%$ alkali concentration was used in the mercerization process. Similar finding was obtained by Das and Chakraborty ${ }^{[33]}$ in their study of the effect of alkali treatment on the strucure and morphology of bamboo fibers.

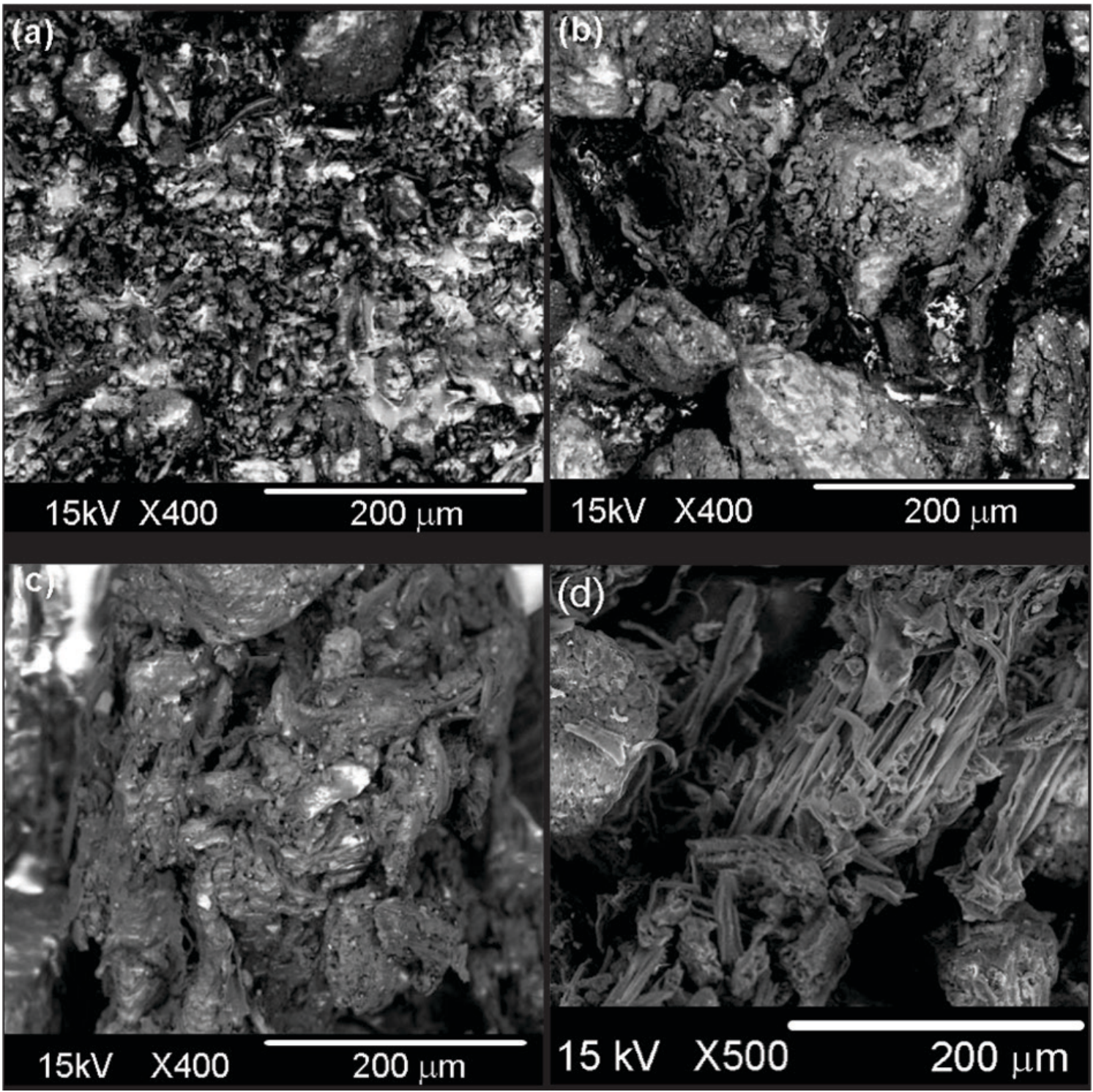

Figure 1. SEM micrographs of (a) untreated castor oil cake; (b) castor oil cake treated with $5 \% \mathrm{NaOH}$ solution; (c) castor oil cake treated with $10 \% \mathrm{NaOH}$ solution; and (d) thinner cellulose fibers in the castor oil cake treated with $5 \% \mathrm{NaOH}$ solution. 


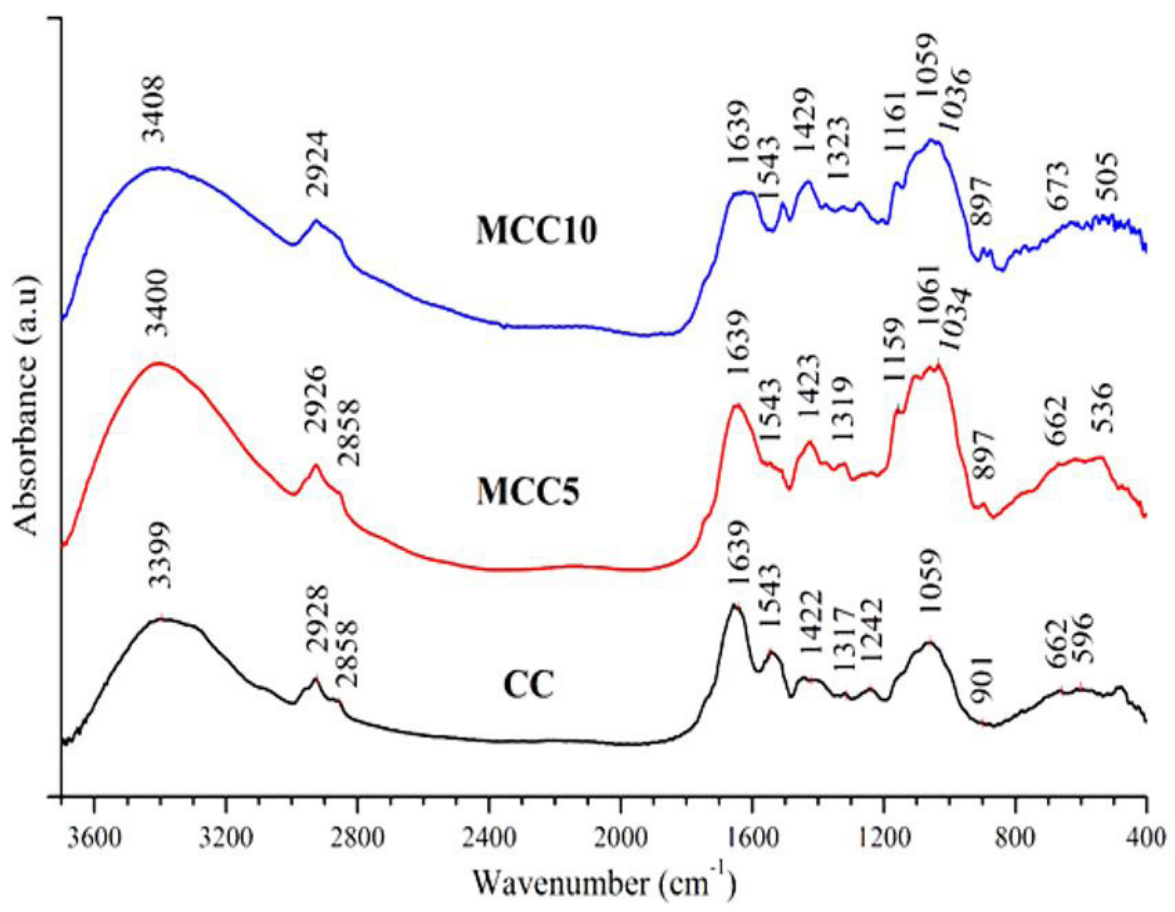

Figure 2. FTIR spectra of the materials under study: CC, MCC5 and MCC10.

The peak at $1639 \mathrm{~cm}^{-1}$ may be ascribed to the absorbed water ${ }^{[33]}$. This band may also be attributed to the carboncarbon streching vibrations in the aromatic ring and may be superimposed with the absorption related to the carbonyl group of ester linkage of lignin ${ }^{[31,34]}$. The intensity of this peak decreased as the alkali concentration increased. Castor oil cake is dark brown. As the fibers were submitted to the mercerization processes, the color of the castor cake became light brown due to the partially removal of lignin. Therefore, the decrease of the intensity of $1639 \mathrm{~cm}^{-1}$ may be attributed to the predominant effect of the removal of lignin due to the alkali treatment.

The IR index for the absorption band at $596 \mathrm{~cm}^{-1}$ is 0.58 for the raw castor cake sample. The IR indices at 5 and $10 \%$ alkali treatment are respectively, 0.56 and 0.62 . The intensity of this absorption band is influenced by the torsional vibration of pyranose ring. Das and Chakraborty ${ }^{[33]}$, in a study of treatment of bamboo fibers with alkali attributed the increase in the IR index value with the increasing of alkali concentration to the removal of cementing material from bamboo fibers, which allows the pyranose ring to undergo more torsional vibration.

Lignin and hemicellulose work on ligocellulosic fibers as a natural barrier for the protection of cellulose. The removal of these substances promotes greater accessibility to cellulose enhancing mechanical anchorage with the polymer matrix.

There is no evidence of absorption bands due to the $\mathrm{CO}$ stretching of carboxilic acids or ester in the samples under study $\left(1730-1734 \mathrm{~cm}^{-1}\right)$. This result suggests that there is no hemicellulose in the castor oil cake or its concentration is very low.

It is worth noting that an unexpected result was obtained. The FTIR pattern of raw castor cake shows strong broad peak at $3399 \mathrm{~cm}^{-1}$, which is characteristic of the $\mathrm{OH}$ streching vibrations. The FTIR indices for this vibration mode corresponding to the $\mathrm{CC}, \mathrm{MCC} 5$ and $\mathrm{MCC} 10$ samples were 1.2, 1.0, and 0.9, respectively. According to Das and Chakraborty ${ }^{[33]}$, the increase of $\mathrm{NaOH}$ concentration should promote the removal of more and more alkali sensitive material. Therefore, an increase in the number of free $\mathrm{OH}$ groups with the increasing of alkali concentration was expected ${ }^{[33]}$. This result may be attributed to the poor resolution of the $\mathrm{OH}$ region. Deconvolution methods must be used in order to obtain a more reliable result.

The FTIR spectra also provide some evidence that the fibers alkali treatment led to the conversion of celullose I into the cellulose II.

Figure 2 shows the maximum absorbance of the hydrogen-bonded $\mathrm{OH}$ streching band was shifted to a higher wavenumber, from 3399 to $3408 \mathrm{~cm}^{-1}$ at $10 \mathrm{wt} \%$ of $\mathrm{NaOH}$. The $\mathrm{CH}$ streching mode was shifted to a lower wavenumber (from 2928 to $2924 \mathrm{~cm}^{-1}$ ). Similar results were obtained by Oh et al. ${ }^{[31]}$. These researchers noticed the absorbance of the hydrogen-bonded $\mathrm{OH}$ streching band shifted from 3352 to $3447 \mathrm{~cm}^{-1}$, when the cellulose was treated with $20 \mathrm{wt} \% \mathrm{NaOH}$. This result was attributed to the intramolecular bonding of $\mathrm{O}(2) \mathrm{H} . . . \mathrm{O}(6)$ of cellulose II, allomorph resulting from the mercerization process. According to Lee et al ${ }^{[35]}$, the characteristic peak of celullose I is at $3270 \mathrm{~cm}^{-1}$. Cellulose II presents two weak additional peaks at $3450 \mathrm{~cm}^{-1}$ and $3480 \mathrm{~cm}^{-1}$. However, it is difficult to identify these weak absorption bands by FTIR as the $\mathrm{OH}$ region is broad and poorly resolved.

The band at $901 \mathrm{~cm}^{-1}$ observed in the spectrum of the raw castor cake is attributed to the $\beta$-glucosidic linkage. This absorption band shifts to a lower wavenumber, $897 \mathrm{~cm}^{-1}$, in 
the spectra of alkali treated fibers. The IR index for the 901 $\mathrm{cm}^{-1}$ with respect to the peak at $1059 \mathrm{~cm}^{-1}$ increases slightly as the alkali concentration increased. In the case of untreated cake, where cellulose occurs as the cellulose I lattice, the IR index is found to be 0.29 . However, treating the castor cake with $5 \%$ and $10 \% \mathrm{NaOH}$ solution increased slightly the IR values, from 0.29 to 0.33 and 0.45 , respectively. These results suggest that there was some change in the lattice structure, when the castor oil cake is treated with $5 \%$ and $10 \% \mathrm{NaOH}$ solution. According to some published studies, conformational changes occurring during decrystallization/conversion of cellulose I to cellulose II may promote alterations in the intensity and sharpness of the FTIR $\beta$-glucosidic linkage absorption band ${ }^{[31,34]}$.

Cellulose I occurs in two allomorphic forms $\left(I_{\alpha}\right.$ and $\left.I_{\beta}\right)$. The cellulose $I_{\beta}$ is the allomorph predominantly found in higher plants ${ }^{[36]}$. According to French ${ }^{[37]}$, the diffractogram of cellulose $I_{\beta}$ presents three main peaks related to the crystallographic planes specified by Miller indices of $(1 \overline{1} 0)$, $(110)$ and (200). These peaks occurs at $2 \theta=15^{\circ}, 17^{\circ}$ and $23^{\circ}$, respectively. The diffractogram of cellulose II also presents three main peaks, located at $2 \theta$ around $12^{\circ}$, and $22^{\circ}$, corresponding to the crystallographic planes $(1 \overline{1} 0)$, $(110)$ and $(020)^{[37,38]}$.

The X-ray diffraction (XRD) pattern of lignocellulosic materials shows characteristic peaks around $16.0^{\circ}, 22.5^{\circ}$ and $34.5^{\circ[39,40]}$. The first two peaks are typical of cellulose ${ }^{[39,40]}$ and the last is attributed to the (004) crystallographic plane of cellulose ${ }^{[41]}$. French ${ }^{[37]}$ describes this peak as a composite of various peaks where the (004) crystallographic plane is not the predominant contributor.

Literature data show, that when there is a large amount of amorphous materials in the lignocellulosic fibers, the peaks corresponding to the planes $(1 \overline{1} 0)$ and $(110)$ appear as a single broad peak ${ }^{[42,43]}$.

Figure 3 shows X-ray diffraction (XRD) patterns of untreated castor cake (CC) and alkali treated castor cake samples: MCC 5 and MCC10.

The XRD pattern of the raw castor cake (CC) shows five diffraction peaks: $15.5^{\circ}, 19.5^{\circ}, 20.8^{\circ}, 21.4^{\circ}$ and $29.5^{\circ}$. The first peak is attributed to the crystallographic planes $(1 \overline{1} 0)$ and (110) of cellulose I and the peak at $2 \theta$ of $21.4^{\circ}$ is assigned to an ordered crystalline arrangement involving intra- or intermolecular hydrogen bond of cellulose. Guimarães et al. ${ }^{[44]}$ found a peak at $2 \theta$ of $21^{\circ}$ in the diffractogram of a castor oil cake. This peak was attributed to an intramolecular bonding of the amino proteins and, or cellulose, but it can be attributed to the crystallographic plane (021) of cellulose $\mathrm{I}^{[45]}$. Although, the presence of the characteristic peaks of cellulose I was detected, evidently, no peak corresponding to the (200) plane of cellulose I was observed. The presence of silica (quartz), which is often used as a fertilizer in agriculture, is evidenced by the peaks at $2 \theta$ of $20.8^{\circ}$ and $26.6^{\circ}{ }^{[46]}$. According to Sánchez-Cantu et al. ${ }^{[4]}$, the peak at $2 \theta$ of $19.5^{\circ}$ is a characteristic signal of crystalline hemicellulose and the peak at $2 \theta$ of $29.5^{\circ}$ is a representative reflection of magnesium calcium carbonates, compounds identified in oil extraction residues.

The mercerization of the castor oil cake caused visible changes in the X-ray pattern The MCC5 besides the peaks attributed to silica and magnesium calcium carbonates shows the characteristic peaks of cellulose I at $2 \theta$ of $16.5^{\circ}$ and $22.5^{\circ}$ corresponding to the (110) and (200) planes, respectively ${ }^{[38]}$. The peak at $2 \theta$ of $21.8^{\circ}$ is attributed to the (020) plane of cellulose $\mathrm{II}^{[38]}$. The presence of one doublet

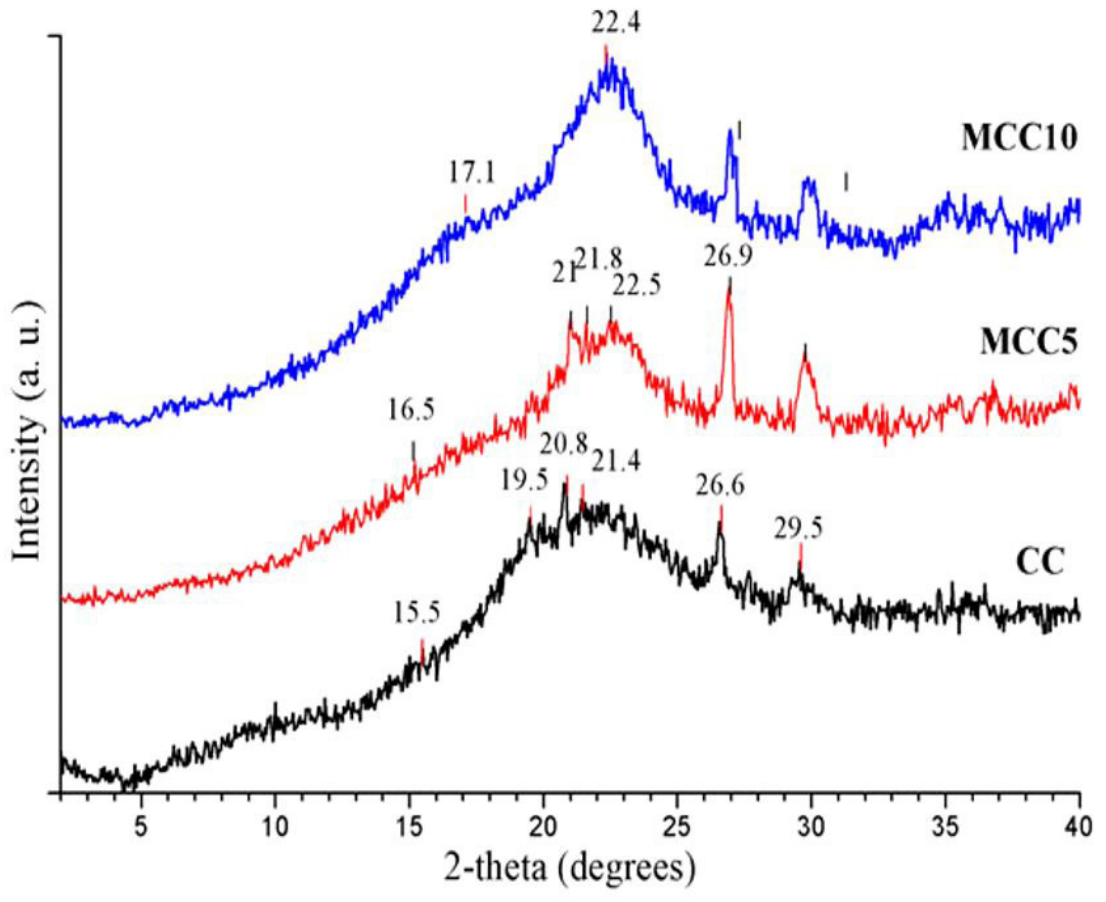

Figure 3. XRD patterns of untreated castor cake (CC) and MCC5 and MCC10 samples. 
at $2 \theta$ around $20^{\circ}$ and $22^{\circ}$ indicates the partial conversion of cellulose I to II ${ }^{[41,48]}$. The peak at $2 \theta$ of $12^{\circ}$ is not always found due to the noise of the experiment ${ }^{[45]}$. The evidence of changing from cellulose I to cellulose II due to the mercerization process is also corroborated by the FTIR spectrum. Sample MCC10 presents a peak at $2 \theta$ of $22.4^{\circ}$ that can be attributed to the (020) plane of cellulose II and to the (200) plane of cellulose $\mathrm{I}^{[37,38]}$. In our view, the mercerization process of castor cake in the experimental conditions used in this work promoted the partial conversion of cellulose I to cellulose II.

The apparent XRD crystallinity index, $\mathrm{CrI}(\%)$, of $\mathrm{CC}$, MCC5 and MCC10 was calculated using the following Equation 1 ${ }^{[49]}$ :

$$
\operatorname{CrI}(\%)=\frac{A_{\text {cryst }}}{A_{\text {total }}} \times 100
$$

where $A_{\text {cryst }}$ is the sum of crystalline band areas and $A_{\text {total }}$ is the total area under the diffractogram. The areas were obtained by using the Origin Lab 8.5 software.

The values obtained were $34.5 \%, 34.9 \%$ and $48.2 \%$ for CC, MCC5 and MCC10 samples, respectively.

Cellulose II is more reactive and more accessible to reagents than cellulose I due to its lower crystallinity, since there is an increased number of inter- and intra-planar hydrogen bonds compared to cellulose $\mathrm{I}^{[49]}$. However, the removal of lignin promotes the increase of crystallinity of the samples.

\subsection{Processing and Characterization of the Composites}

The torque rheometer is commonly used in polymer processing laboratories as it can simulate mixing and shaping processes in nearly real processing conditions ${ }^{[50]}$. For a pure polymer if the torque values were corrected to minimize the effect of the viscous dissipation, the steady-state torque can be related to the viscosity data obtained from capillary and parallel plate rheometers ${ }^{[51]}$. Here, as mentioned before, the torque rheometer was used to produce the LDPE/PHB/CC, LDPE/PHB/CCM5 and LDPE/PHB/CCM10 composites at $80 / 10 / 10 \mathrm{wt} \%$. Figure 4 shows the torque versus time curves of the LDPE and those of the composite materiais. Figure 4 also shows the torque versus time curve of LDPE/ PHB (90/10) blend. All curves have a similar profile. High torque values are initially observed, as the initial minutes of mixing involve the shearing of solid materials in addition to the effect of temperature. This continuos shearing action promotes the melting of the polymers. A lower resistance to rotor's shearing action is observed, leading to lower torque values, which decrease with the stabilization of the the melting process. Then, a stable torque is obtained ${ }^{[52]}$.

A slight increase in stable torque is observed when $10 \mathrm{wt} \%$ of PHB is added to LDPE. Some published studies on blends of LDPE/PHB and LLDPE/PHB show that the incorporation of $10 \mathrm{wt} \%$ of $\mathrm{PHB}$ into the polymer matrices does not cause significant changes in the values of melt flow index (MFI) of polyolefins ${ }^{[53,54]}$. Karami et al. ${ }^{[55]}$ found that the complex viscosity of the LDPE samples with less than $50 \mathrm{wt} \%$ of $\mathrm{PHB}$ content were greater than that of the neat LDPE. However, this work does not give any indication as to whether the Cox-Merz rule is valid for the LDPE/PHB samples. This finding requires further investigation. Some interaction between these two polymers may be taking place under these experimental conditions.

In general, the mercerization of natural fibers promotes the obtaining of better mechanical properties due to the

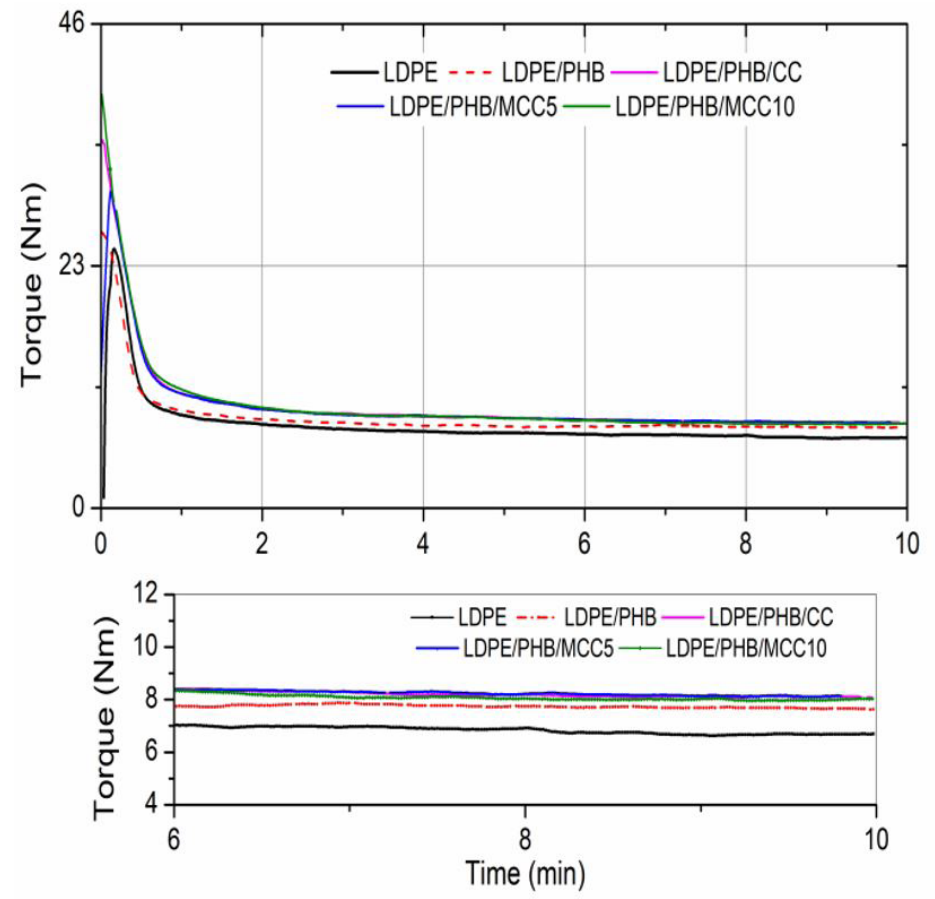

Figure 4. Torque versus time curves of LDPE, LDPE/PHB blend, and LDPE/PHB/CC and LDPE/PHB/MCC composites. 
Table 1. Elastic modulus and Tensile strenght of the LDPE/PHB/CC and LDPE/PHB/MCC composites.

\begin{tabular}{ccc}
\hline Composites & Elastic modulus (MPa) & Tensile strenght(MPa) \\
\hline LDPE/PHB/CC & $81.8 \pm 5.3$ & $4.21 \pm 0.38$ \\
LDPE/PHB/MCC5 & $199.1 \pm 22.4$ & $6.55 \pm 0.24$ \\
LDPE/PHB/MCC10 & $100.5 \pm 14.9$ & $4.50 \pm 0.7$ \\
\hline
\end{tabular}

modification of surface topography and diameter of the fibers resulting in improved interfacial adhesion properties ${ }^{[7,10,14]}$.

Table 1 shows elastic modulus and tensile strength of the LDPE/PHB composites filled with the untreated castor oil cake (CC) and with the alkali treated fibers (MCC5 and MCC10).

The mercerization process promotes an increase of the surface area of the fiber contact with the polymeric matrix due to the increase in the aspect ratio and the roughness of the fiber. As a result, in general, the incorporation of mercerized fibers into the polymeric matrices increases the elastic modulus ${ }^{[8-12]}$. Table 1 shows that the mercerization process of the castor oil cake leads to the increasing of the tensile elastic modulus of the composites. However, this effect is more evident, when the fiber was treated with $5 \%$ $\mathrm{NaOH}$ solution. According to Kabir et al. ${ }^{[49]}$, if the alkali concentration is higher than the optimum condition, an excess of delignification may occur, which weakens or damages the fibers. In the present work, as the concentration of $\mathrm{NaOH}$ increased from $5 \%$ to $10 \%$, the fibers became whiter due to the more efficient removal of lignin.

The tensile strength is a function of the surface area of the fiber's contact with the polymer matrix and the interfacial adhesion. In general, the hydrophilic nature of the fibers hinders its effective interaction with hydrophobic polymeric matrices. The mercerization process removes lignin and hemicelluloses from the surface of the fiber improving the interactions between the fiber and the polymer matrices ${ }^{[8]}$. In the treatment of the fibers with $\mathrm{NaOH}$, there is a reaction between the hydroxyl groups $(\mathrm{OH})$ of the fiber with the alkaline solution (Equation 2) ${ }^{[56]}$, which reduces the water absorption of the fibers and improves the compatibility between them and the polymeric matrice ${ }^{[10]}$. As a result, there is an increase in the tensile strength.

$$
\text { Fiber }-\mathrm{O}-\mathrm{H}+\mathrm{NaOH} \rightarrow \text { Fiber }-\mathrm{O}^{+} \mathrm{Na}^{-}+\mathrm{H}_{2} \mathrm{O}
$$

Table 1 shows that fiber mercerization with $5 \%$ $\mathrm{NaOH}$ solution generates higher tensile strength values of composites. However, the alkali treatment of the fibers with $10 \% \mathrm{NaOH}$ solution does not promote a significant increase in the tensile strength.

There is some controversy about the effect of the mercerization of the fibers on the mechanical behavior of the composites obtained ${ }^{[8]}$. Some authors attributed the decrease in the tensile strength of the composites developed with alkali treated fibers to the changes from crystalline cellulose I into cellulose II, which is less crystalline than cellulose $\mathrm{I}^{[57]}$. In the present work, the mercerization process with both concentrations of $\mathrm{NaOH}$ solution results in the partial formation of cellulose II as evidenced by FTIR data. However, the treatment of the fibers with $10 \% \mathrm{NaOH}$ solution increases significantly the apparent XRD crystallinity index of the castor oil cake. This increase is due to the more efficient removal of lignin, waxes, and other impurities. Therefore, the partial breakdown of the fibers caused by the higher concentration of $\mathrm{NaOH}$ may be responsible by the lower tensile strength values of the composite filled with MCC10.

\section{Conclusions}

In this work, the effects of mercerization on castor oil cake structure and tensile properties of LDPE/PHB/castor oil cake composites were investigated. FTIR and XRD data indicated that there was a partial formation of cellulose II, as well as the removal of lignin and other impurities. The morphological analysis of the mercerized fibers by SEM showed that the extraction of hemicelluloses, lignin and waxes gave rise to thinner cellulose fibers and increased roughness that in turn may promote greater contact area between these fibers with the polymeric matrix. The mercerization process performed with $5 \% \mathrm{NaOH}$ solution improved the tensile properties of the LDPE/PHB/castor cake composites. The elastic modulus and tensile strength values of composites filled with the fibers treated with 5\% $\mathrm{NaOH}$ solution were superior to those obtained with $10 \%$ $\mathrm{NaOH}$ solution. This result suggests that the higher $\mathrm{NaOH}$ concentration compromises the integrity of the fibers, deteriorating the mechanical properties.

\section{Acknowledgments}

This study was financed in part by the Coordenação de Aperfeiçoamento de Pessoal de Nível Superior - Brazil (CAPES) - Finance Code 001. We also thank Conselho Nacional para o Desenvolvimento Científico e Tecnológico $(\mathrm{CNPq})$ and Fundação de Amparo à Pesquisa do Estado do Rio de Janeiro (FAPERJ) for financial support and BRASKEM, PHB Industrial S.A. and Bom-Brasil Óleo de Mamona Ltda. for providing the LDPE resin, the PHB and castor oil cake, respectively.

\section{References}

1. Nayan, N. H. M., Razak, S. I. A., Rahman, W. A. W., \& Majid, R. A. (2013). Effects of mercerization on the properties of paper produced from Malaysian pineapple leaf fiber. IACSIT International Journal of Engineering and Technology, 13(4), $1-6$.

2. Abdullah, N. M., \& Ahmad, I. (2012). Effect of chemical treatment on mechanical and water-sorption properties coconut fiber-unsaturated polyester from recycled PET. International Scholarly Research Notices, 2012, 1-8. http:// dx.doi.org/10.5402/2012/134683.

3. Väisänen, T., Haapala, A., Lappalainen, R., \& Tomppo, L. (2016). Utilization of agricultural and forest industry waste and residues in natural fiber-polymer composites: A review. Waste Management, 54, 62-73. http://dx.doi.org/10.1016/j. wasman.2016.04.037. PMid:27184447. 
4. Satyanarayana, K. G., Arizaga, G. G. C., \& Wypych, F. (2009). Biodegradable composites based on lignocellulosic fibers An overview. Progress in Polymer Science, 34(9), 982-1021. http://dx.doi.org/10.1016/j.progpolymsci.2008.12.002.

5. Peças, P., Carvalho, H., Salman, H., \& Leite, M. (2018). Natural fiber composites and their applications: A review. Journal of Composite Science, 2(4), 66-85. http://dx.doi.org/10.3390/ jes2040066.

6. Rohan, T., Tushar, B., \& Mahesha, G. T. (2018). Review of natural fiber composites. IOP Conference Series. Materials Science and Engineering, 314, 1-8. http://dx.doi.org/10.1088/1757899X/314/1/012020.

7. Hashim, M. Y., Roslan, M. N., Amin, A. M., Zaidi, A. M. A., \& Ariffin, S. (2012). Mercerization treatment parameter effect on natural fiber reinforced polymer matrix composite: A brief review. World Academy of Science, Engineering and Technology, 6(8), 1378-1384. http://dx.doi.org/10.5281/zenodo.1059511.

8. Paukszta, D., \& Borysiak, S. (2013). The influence of processing and the polymorphism of lignocellulosic fillers on the structure and properties of composite materials-A review. Materials, 6(7), 2747-2767. http://dx.doi.org/10.3390/ma6072747. PMid:28811406.

9. Albinante, S. R., Pacheco, E. B., \& Visconte, L. L. (2013). Revisão dos tratamentos químicos da fibra natural para misturas com poliolefinas. Quimica Nova, 36(1), 114-122. http://dx.doi. org/10.1590/S0100-40422013000100021.

10. Liu, X. Y., \& Dai, G. C. (2007). Surface modification and micromechanical properties of jute fiber mat reinforced polypropylene composites. Express Polymer Letters, 1(5), 299-307. http://dx.doi.org/10.3144/expresspolymlett.2007.43.

11. Mokaloba, N., \& Batane, R. (2014). The effects of mercerization and acetylation treatments on the properties of sisal fiber and its interfacial adhesion characteristics on polypropylene. International Journal of Engineering Science and Technology, 6(4), 83-97. http://dx.doi.org/10.4314/ijest.v6i4.9.

12. Kabir, M. M., Wang, H., Aravinthan, T., Cardona, F., \& Lau, K. T. (2011). Effects of natural fibre surface on composite properties: a review. In 1st International Postgraduate Conference on Engineering, Designing and Developing the Built Environment for Sustainable Wellbeing - eddBE2011 (pp. 94-99). Brisbane, Australia: USQ ePrints.

13. Liu, Y., \& Hu, H. (2008). X-ray diffraction study of bamboo fibers treated with $\mathrm{NaOH}$. Fibers and Polymers, 9(6), 735-739. http://dx.doi.org/10.1007/s12221-008-0115-0.

14. Jaramillo-Quiceno, N., Vélez, R. J. M., Cadena, Ch. E. M., Restrepo-Osorio, A., \& Santa, J. F. (2018). Improvement of mechanical properties of pineapple leaf fibers by mercerization process. Fibers and Polymers, 19(12), 2604-2611. http://dx.doi. org/10.1007/s12221-018-8522-3.

15. Xia, Y., Xian, G., \& Li, H. (2014). Enhancement of tensile properties of flax filaments through mercerization under sustained tension. Polymers \& Polymer Composites, 22(2), 203-208. http://dx.doi.org/10.1177/096739111402200218.

16. Kalia, S., Kaith, B. S., \& Kaur, I. (2009). Pretreatments of natural fibers and their application as reinforcing material in polymer composites - A review. Polymer Engineering and Science, 49(7), 1253-1272. http://dx.doi.org/10.1002/pen.21328.

17. Chandrasekar, M., Ishak, M. R., Sapuan, S. M., Leman, Z., \& Jawaid, M. (2017). A review on the characterisation of natural fibres and their composites after alkali treatment and water absorption. Plastics, Rubber and Composites, 46(3), 119-136. http://dx.doi.org/10.1080/14658011.2017.1298550.

18. Baldoni, A. B., Carvalho, M. H., Souza, N. L., Nobrega, M. B. M., Milani, M., \& Aragão, F. J. L. (2011). Variability of ricin content in mature seeds of castor bean. Pesquisa Agropecuária
Brasileira, 46(7), 776-779. http://dx.doi.org/10.1590/S0100204X2011000700015.

19. Melo, W. C., Santos, A. S., Santa Anna, L. M. M., \& Pereira, N. $\mathrm{Jr}$ (2008). Acid and enzymatic hydrolysis of the residue from castor bean (Ricinus communis L.) oil extraction for ethanol production: detoxification and biodiesel process integration. Journal of the Brazilian Chemical Society, 19(3), 418-425. http://dx.doi.org/10.1590/S0103-50532008000300008.

20. Patel, V. R., Dumancas, G. G., Kasi Viswanath, L. C., Maples, R., \& Subong, B. J. (2016). Castor oil: Properties, uses, and optimization of processing parameters in commercial production. Lipid Insights, 9, 1-12. http://dx.doi.org/10.4137/LPI.S40233. PMid:27656091.

21. Keera, S. T., El Sabagh, S. M., \& Taman, A. R. (2018). Castor oil biodiesel production and optimization. Egyptian Journal of Petroleum, 27(4), 979-984. http://dx.doi.org/10.1016/j. ejpe.2018.02.007.

22. Treinyte, J., Grazuleviciene, V., \& Ostrauskaite, J. (2014). Biodegradable polymer composites with nitrogen- and phosphorous- containing waste materials as the fillers. Ecological Chemistry and Engineering. S, 21(3), 515-528. http://dx.doi. org/10.2478/eces-2014-0038.

23. Nwigbo, S. C., Okafor, T. C., \& Atuanya, C. U. (2013). The mechanical properties of castor seed shell-polyester matrix composites. Research Journal of Applied Sciences, Engineering and Technology, 5(11), 3159-3164. http://dx.doi.org/10.19026/ rjaset.5.4551.

24. Satyanarayana, K. G., \& Prasad, V. S. (2016). Starch-based “Green" composites. In S. Kalia (Ed.), Biodegradable green composites (pp. 199-298). New Jersey: John Wiley \& Sons Inc. http://dx.doi.org/10.1002/9781118911068.ch8.

25. Stork, R. R., \& Rocha, M. C G. G. G. (2010). Composites of low- density polyethylene and castor presscake. PolymerPlastics Technology and Engineering, 49(13), 1352-1355. http://dx.doi.org/10.1080/03602559.2010.496699.

26. Burlein, G. A., \& Rocha, M. C. G. (2014). LDPE/PHB blends filled with castor oil pressed cake. Materials Research, 17(1), 203-212. http://dx.doi.org/10.1590/S1516-14392013005000166.

27. Assmann, V. (2009). Obtenção de compósitos termomoldados a partir da torta de mamona plastificada com glicerol, derivado do processo de transesterificação de óleos e gorduras (Master's Thesis). Universidade Federal do Paraná, Curitiba.

28. Burlein, G. A., \& Rocha, M. C. G. (2014). Mechanical and morphological properties of LDPE/PHB blends filled with castor oil pressed cake. Materials Research, 17(1), 97-105. http://dx.doi.org/10.1590/S1516-14392013005000196.

29. Ribeiro, C. M., Castilho, L. R., Freire, D. M., Dias, M. L., Machado, A. C., Cunha, L. M., \& Nazareth, N. J. (2010). BR Patent PI080410-6. Brazil. Base de Dados PATENTSCOPE®.

30. American Society for Testing and Materials-ASTM. (2014). ASTM D638-14: Standard test method for tensile properties of plastics. West Conshohocken, PA: ASTM International. Retrieved in 2020, August 11, from www.astm.org

31. Oh, S. Y., Yoo, D. I., Shin, Y., Kim, H. C., Kim, H. Y., Chung, Y. S., Park, W. H., \& Youk, J. H. (2005). Crystalline structure analysis of cellulose treated with sodium hydroxide and carbon dioxide by means of X-ray diffraction and FTIR spectroscopy. Carbohydrate Research, 340(15), 2376-2391. http://dx.doi. org/10.1016/j.carres.2005.08.007 PMid:16153620.

32. Kondo, T. (1997). The assignment of IR absorption bands due to free hydroxyl groups in cellulose. Cellulose, 4(4), 281-292. http://dx.doi.org/10.1023/A:1018448109214.

33. Das, M., \& Chakraborty, D. (2006). Influence of alkali treatment on the fine structure and morphology of bamboo fibers. Journal of Applied Polymer Science, 102(5), 5050-5056. http://dx.doi. org/10.1002/app.25105. 
34. Yue, Y., Zhou, C., French, A. D., Xia, G., Han, G., Wang, Q., $\& \mathrm{Wu}, \mathrm{Q}$. (2012). Comparative properties of cellulose nanocrystals from native and mercerized cotton fibers. Cellulose, 19(4), 1173-1187. http://dx.doi.org/10.1007/s10570-012-9714-4.

35. Lee, C. M., Mittal, A., Barnette, A. L., Kafle, K., Park, Y. B., Shin, H., Johnson, D. K., Park, S., \& Kim, S. H (2013). Cellulose polymorphism study with sum-frequency-generation (SFG) vibration spectroscopy: identification of exocyclic $\mathrm{CH} 2 \mathrm{OH}$ conformation and chain orientation. Cellulose, 20(3), 991-100. http://dx.doi.org/10.1007/s10570-013-9917-3.

36. Park, S., Baker, J. O., Himmel, M. E., Parilla, P. A., \& Johnson, D. K. (2010). Cellulose crystallinity index: measurement techniques and their impact on interpreting cellulose performance. Biotechnology for Biofuels, 3(1), 1-10. http:// dx.doi.org/10.1186/1754-6834-3-10. PMid:20497524.

37. French, A. D. (2014). Idealized powder diffraction patterns for cellulose polymorphs. Cellulose (London, England), 21(2), 885-896. http://dx.doi.org/10.1007/s10570-013-0030-4.

38. Kafle, K., Greeson, K., Lee, C., \& Kim, S. H. (2014). Cellulose polymorphs and physical properties of cotton fabrics processed with commercial textile mills for mercerization and liquid ammonia treatments. Textile Research Journal, 84(16), 16921699. http://dx.doi.org/10.1177/0040517514527379.

39. El Halal, Sh. L., Colussi, R., Deon, V. G., Pinto, V. Z., Villanova, F. A., Carreño, F. L. V., Dias, R. G., \& Zavareze, R. (2015). Films based on oxidized starch and cellulose from barley. Carbohydrate Polymers, 133, 644-653. http://dx.doi. org/10.1016/j.carbpol.2015.07.024. PMid:26344323.

40. Oliveira, J. P., Bruni, G. P., Lima, K. O., El Halal, S. L. M., da Rosa, G. S., Dias, A. R. G., \& Zavareze, E. da R. (2017). Cellulose fibers extracted from rice and oat husks and their application in hydrogel. Food Chemistry, 221, 153-160. http:// dx.doi.org/10.1016/j.foodchem.2016.10.048. PMid:27979125.

41. Carrillo-Varela, I., Pereira, M., \& Mendonça, R. T. (2018). Determination of polymorphic changes in cellulose from Eucalyptus spp. fibres after alkalization. Cellulose, 25, 68316845. http://dx.doi.org/10.1007/s10570-018-2060-4.

42. Mondragon, G., Fernandes, S., Retegi, A., Peña, C., Algar, I., Eceiza, A., \& Arbelaiz, A. (2014). A common strategy to extracting cellulose nanoentities from different plants. Industrial Crops and Products, 55, 140-148. http://dx.doi.org/10.1016/j. indcrop.2014.02.014.

43. Yang, D., Zhong, L.-X., Yuan, T.-Q., Peng, X.-W., \& Sun, R.-C. (2013). Studies on the structural characterization of lignin, hemocellulose and cellulose fractioned by ionic liquid followed by alkaline extraction from bamboo. Industrial Crops and Products, 43, 141-149. http://dx.doi.org/10.1016/j. indcrop.2012.07.024.

44. Guimarães, J. L., Trindade Cursino, A. C., Ketzer Saul, C., Sierrakowski, M. R., Ramos, L. P., \& Satyanarayana, K. (2016). Evaluation of castor oil cake starch and recovered glycerol and development of "Green" composites based on those with plant fibers. Materials, 9(2), 76. http://dx.doi.org/10.3390/ ma9020076. PMid:28787878.

45. Lengowski, E. C. (2012). Caracterização e predição da cristalinidade de celulose através de espectroscopia no infravermelho e análise multivariada (Master's Thesis). Universidade Federal do Paraná, Curitiba.

46. de Carvalho Jr, A. B. (2010). Preparação e caracterização de quartzo particulado e discos quartzo-teflon para dosimetria termoluminiscente das radiações ionizantes (Doctoral Dissertation). Universidade Federal de Pernambuco, Recife.

47. Sánchez-Cantú, M., Ortiz-Moreno, L., Ramos-Cassellis, M. E., Marín-Castro, M., \& De la Cerna-Hernández, C. (2018). Solid-state treatment of castor cake employing the enzymatic cocktail produced from pleurotus djamor fungi. Applied Biochemistry and Biotechnology, 185(2), 434-449. http:// dx.doi.org/10.1007/s12010-017-2656-4. PMid:29178055.

48. Goldberg, R. N., Schliesser, J., Mittal, A., Decker, S. R., Santos, A. F. L. O. M., Freitas, V. L. S., Urbas, A., Lang, B. E., Heiss, C., Ribeiro da Silva, M. D. M. C., Woodfield, B. F., Katahira, R., Wang, W., \& Johnson, D. K. (2015). A thermodynamic investigation of the cellulose allomorphs: Cellulose (am), cellulose I $\beta$ (cr), cellulose II (cr) and cellulose III (cr). The Journal of Chemical Thermodynamics, 81, 184-226. http:// dx.doi.org/10.1016/j.jct.2014.09.006.

49. Kabir, M. M., Wang, H., Lau, K. T., \& Cardona, F. (2012). Chemical treatments on plant-based natural fibre reinforced polymer composites: an overview. Composites. Part B, Engineering, 43(7), 2883-2892. http://dx.doi.org/10.1016/j. compositesb.2012.04.053

50. Ferreira, D. P., Cruz, J., \& Fangueiro, R. (2019). Surface modification of natural fibers in biopolymer composites. In G. Koronis \& A. Silva (Eds.), Woodhead Publishing series in Composites Science and Enginering, Green composites for automotive applications (pp. 3-41). Duxford, UK: Woodhead Publishing.

51. Izani, M. A., Paridah, M. T., Anwar, U. M., Nor, M. Y. M., \& H'ng, P. S. (2013). Effects of fiber treatment on morphology, tensile and thermogravimetric analysis of oil palm empty fruit bunches fibers. Composites. Part B, Engineering, 45(1), 12511257. http://dx.doi.org/10.1016/j.compositesb.2012.07.027.

52. Wang, C., Wang, J., Yu, C., Wu, B., Wang, Y., \& Li, W. (2014). A novel method for the determination of seady-torque of polymer melts by HAAKE MiniLab. Polymer Testing, 33, 138-144. http://dx.doi.org/10.1016/j.polymertesting.2013.12.001.

53. Santi C.R., Hage Jr, E., Correa, C. A. \& Vlachopoulos, J. (2009). Torque viscometry of molten polymers and composites. Applied Rheology, 19(1), 13148-1-13148-7.

54. Pang, A. L., Bakar, A. A., \& Ismail, H. (2015). Effects of Kenaf loading on processability and properties of linera low density polyethylene/poly(vinyl alcohol)/Kenaf composites. BioResources, 10(4), 7302-7314. http://dx.doi.org/10.15376/ biores.10.4.7302-7314.

55. Burlein, G. A. (2010). Avaliação das propriedades de polietileno de baixa densidade (PEBD), poli(3-hidroxibutirato) (PHB) $e$ de suas misturas com torta de mamona (Master's Thesis). Universidade do Estado do Rio de Janeiro, Brazil.

56. Rigotti, D., Dorigato, A., \& Pegoretti, A. (2020). ThermoMechanical Behavior and Hydrolitic degradation of Linear Low Density Polyethylene/Poly (3-Hydroxybutirate) Blends. Frontier in Materials, 7(31), 1-11. http://dx.doi.org/10.3389/ mats2020.0031.

57. Karami, S., Nazockdast, H., Ahmadi, Z., Rabolt, J. F., Noda, I., $\&$ Chase, D. B. (2019). Microstructure effects on the rheology of nanoclay-filled PHB/LDPE blends. Polymer Composites, 40(10), 4125-4134. http://dx.doi.org/10.1002/pc.25273.

Received: Aug. 11, 2020 Revised: Nov. 10, 2020

Accepted: Nov. 26, 2020 